\title{
Microstructure and wear behavior of austempered high carbon high silicon steel
}

\author{
Palaksha Acharya ${ }^{1 *}$, Ajit Kumar ${ }^{1}$ and Ravishankar Bhat ${ }^{1}$ \\ ${ }^{1}$ Department of Metallurgical and Materials Engineering, National Institute of Technology \\ Karnataka, Surathkal, Mangaluru 575025, India.
}

\begin{abstract}
In the present investigation, the influence of austempering temperature and time on the microstructure and dry sliding wear behavior of high silicon steel was studied. The test specimens were initially austenitised at $900^{\circ} \mathrm{C}$ for 30 minutes, thereafter austempered at various temperatures $280^{\circ} \mathrm{C}, 360^{\circ} \mathrm{C}$ and $400^{\circ} \mathrm{C}$, for varying duration from 30 to 120 minutes. These samples after austempering heat treatment were subsequently air cooled to room temperature, to generate typical ausferritic microstructures and then correlated with the wear property. The test outcomes demonstrate the slight increase in specific wear rate with increase in both austempering temperature and time. Specific wear rate was found to be minimum at an austempering temperature of $280^{\circ} \mathrm{C}$, that exhibits lower bainite microstructure with high hardness, on the other hand specific wear rate was found to be slightly high at increased austempering temperatures at $360^{\circ} \mathrm{C}$ and $400^{\circ} \mathrm{C}$, due to the upper bainite structure that offered lower hardness to the matrix. The sample austempered at $280^{\circ} \mathrm{C}$ for 30 minutes offered superior wear resistance when compared to other austempering conditions, mainly due to the presence of fine acicular bainitic ferrite along with stabilized retained austenite and also some martensite in the microstructure.
\end{abstract}

\section{Introduction}

Steels with an ausferritic structure (i.e., a blend of ferrite and carbon rich austenite) have a few points of interest including high strength, great toughness, superior wear resistance relying on the transformation temperature and time [1]. The extraordinary blend of these properties with that of the low expenses of the raw material and heat treatment contrasted with customary steels discover their utilization in various fields like automotive, railway components and cutting tools applications [2]. Manganese content in steel underneath $2 \%$ favours hardenability, which adds to solute strengthening [3]. The deleterious effect of cementite is overcome by smothering their precipitation by adding adequate quantity of silicon (atleast 1.5 wt. \%) [4], due to insolubility of silicon in cementite. Thus carbon remains in and stabilizes austenite [5].

\footnotetext{
${ }^{*}$ Corresponding author: palaksha.pa@gmail.com
} 
The present investigation was focused to evaluate the effect of varying austempering heat treatment parameters on the microstructure and wear behavior of AISI 9260 high silicon steel.

\section{Experimental procedures}

The test steel used for the present research work is AISI 9260 steel in the form of cylindrical rolled bars of $13 \mathrm{~mm}$ diameter and $1000 \mathrm{~mm}$ long. The as-received steel was checked for its chemical composition using optical emission spectrometer, with composition details shown in table 1 .

Table 1. Chemical composition of the as-received AISI 9260 steel (weight \%)

\begin{tabular}{|c|l|l|c|c|c|c|c|c|c|}
\hline $\mathrm{C}$ & $\mathrm{Si}$ & $\mathrm{Mn}$ & $\mathrm{Cr}$ & $\mathrm{Ni}$ & $\mathrm{Mo}$ & $\mathrm{Cu}$ & $\mathrm{V}$ & $\mathrm{S}$ & $\mathrm{P}$ \\
\hline 0.6 & 2.06 & 0.84 & 0.13 & 0.019 & 0.007 & 0.009 & 0.002 & 0.005 & 0.013 \\
\hline
\end{tabular}

Wear test specimens were machined from the as-received AISI 9260 steel bars, with dimensions $8 \mathrm{~mm}$ diameter and $25 \mathrm{~mm}$ length, which is as per ASTM G99 standard [6].

To perform austempering heat treatment, the machined specimens were subjected to full austenitisation at $900^{\circ} \mathrm{C}$ for about 30 minutes in a muffle furnace and there after quenched in a molten salt bath, (mixture of $45 \% \mathrm{NaNO}_{3}$ and $55 \% \mathrm{KNO}_{3}$ ) maintained at various temperatures $\left(280^{\circ} \mathrm{C}, 360^{\circ} \mathrm{C}\right.$ and $\left.400^{\circ} \mathrm{C}\right)$ and varying duration of $30,60,90$ and 120 minutes for each temperatures.

For microstructural analysis, the austempered specimens were metallographically polished and etched with $2 \%$ nital $\left(98 \mathrm{ml}\right.$ concentrated $\mathrm{HNO}_{3}$ and $2 \mathrm{ml}$ ethanol), then observed under JEOL JSM-6380LA scanning electron microscope (SEM). SEM was also used to characterize the worn out surfaces of the samples in order to understand the wear mechanisms. X-ray diffractometer (XRD) analysis was carried out using JEOL-JDX-8P $\mathrm{XRD}$ (operated with $\mathrm{Cu}-\mathrm{K} \alpha$ radiation at $30 \mathrm{KV}$ and $20 \mathrm{~mA}$ ), scanned in the $2 \theta$ range of $40^{\circ}$ to $50^{\circ}$ and at a scan speed of one degree per minute.

The hardness tests were carried out for all the austempered samples using Shimadzu HMV-G 20ST Vickers hardness tester ( $1 \mathrm{~kg}$ load for dwell time of 15 seconds). The average of at least five readings was reported as hardness values.

Pin-on-disc apparatus was used to evaluate the dry sliding wear behavior of the austempered specimens, under a fixed load of $2 \mathrm{~kg}$, wear track diameter set to $120 \mathrm{~mm}$ and disc speed of $1000 \mathrm{rpm}$, Wear test was performed for duration of three hours in a cumulative way i.e. the worn specimens were weighed every half an hour. Specific wear rate (SWR) was registered toward the finish of three hours, using the equation (1).

$$
\operatorname{SWR}\left(m m^{3} / N-m\right)=\frac{\Delta w}{\rho \times L \times d}
$$

$\Delta \mathrm{w}=$ weight loss (grams),$\rho=$ Density of the test steel $\left(\mathrm{gram} / \mathrm{mm}^{3}\right), \mathrm{L}=$ load (Newton), $\mathrm{d}=$ sliding distance (meters). 


\section{Results and discussion}

\subsection{Microstructure}

(Fig. 1(a-f)) demonstrates the microstructural investigations of the various austempered specimens that exhibits bainitic structure that comprises of ferrite, retained austenite and presence of some martensite as well.

Austempering at lower temperature i.e. at $280^{\circ} \mathrm{C}$ for 30 minutes reveals acicular structured bainitic ferrite, retained austenite and martensite (Fig. 1(a)), which is because of high nucleation rates of ferrite and furthermore expanded level of supercooling of bainitic transformation and lower carbon diffusion rates.
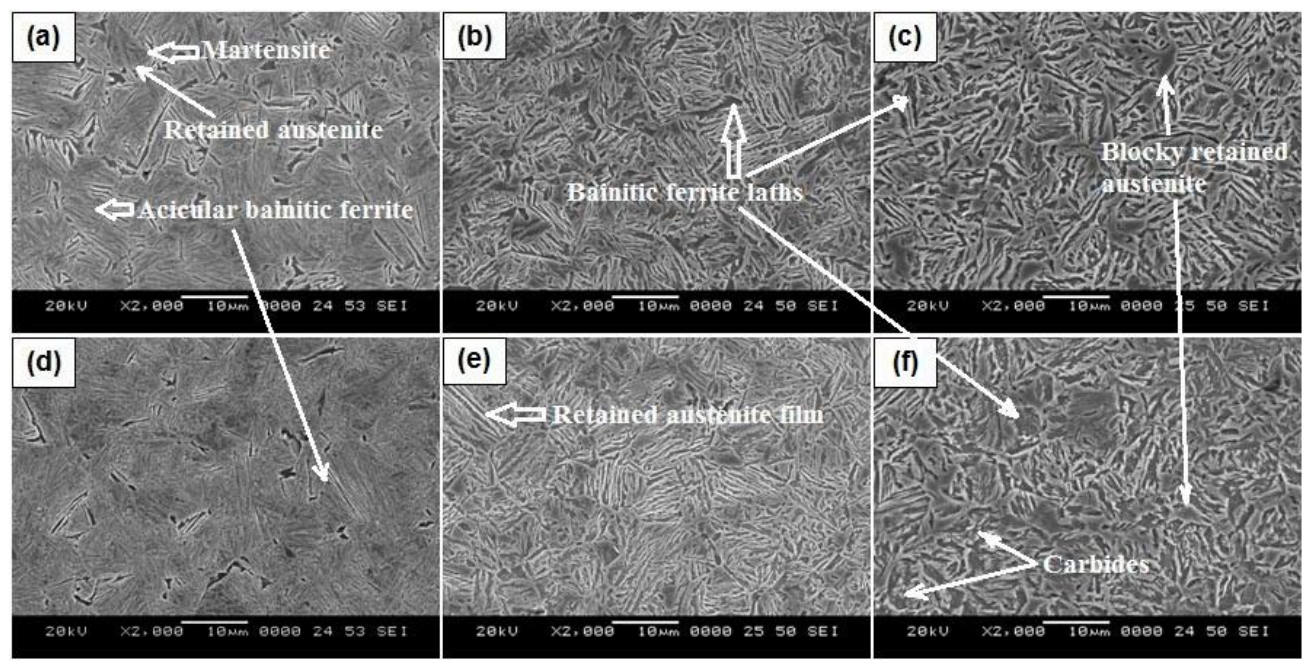

Fig. 1. Scanning electron micrographs of the specimens austempered at various temperatures and duration (a) $280^{\circ} \mathrm{C}-30 \mathrm{~min}$. (b) $360^{\circ} \mathrm{C}-30 \mathrm{~min}$. (c) $400^{\circ} \mathrm{C}-30 \mathrm{~min}$. (d) $280^{\circ} \mathrm{C}-120 \mathrm{~min}$. (e) $360^{\circ} \mathrm{C}-$ $120 \mathrm{~min}$. (f) $400^{\circ} \mathrm{C}-120 \mathrm{~min}$.

(Fig. 1(b \& c)) exhibits the microstructures of specimens austempered at $360^{\circ} \mathrm{C}$ and $400^{\circ} \mathrm{C}$ for a duration of 30 minutes, where impressive measure of retained austenite and bainitic ferrite with enlarged laths (upper bainite) was noticed, due to the extremely high carbon diffusion rates from bainitic ferrite to the adjoining retained austenite, which stimulates the growth rate of bainitic ferrite which thus causes augmenting of ferrite laths.

Referring to the Fig. 1(d, e \& f) which shows the impact of increment in austempering time $\left(120\right.$ minutes for temperatures $280^{\circ} \mathrm{C}, 360^{\circ} \mathrm{C}$ and $\left.400^{\circ} \mathrm{C}\right)$ where fineness in the microstructure was seen, due to the adequate availability of time for further nucleation of bainitic ferrite needles, bringing about lessened retained austenite content at $280^{\circ} \mathrm{C}$ (Fig. 1(d)). However at elevated austempering temperature i.e., at $360^{\circ} \mathrm{C}$ adequate availability of time for growth of bainitic ferrite laths and finally at $400^{\circ} \mathrm{C}$, isothermal holding for longer duration actuates the second stage response of bainitic transformation, where carbides get precipitated in retained austenite (Fig. 1(f)), which reduces the retained austenite content and were confirmed from XRD analysis displayed in the figure 2(c).

\subsection{X-ray diffractometry}

XRD studies were carried out to estimate retained austenite and bainitic ferrite quantitatively by direct comparison method suggested by B. D. Cullity [7]. 
Figure 2(c) demonstrates that for all austempering time, the retained austenite content increases from $280^{\circ} \mathrm{C}$ to $360^{\circ} \mathrm{C}$ and after that drops at $400{ }^{\circ} \mathrm{C}$ (except for 30 minutes). In addition to this decrease in the retained austenite content was observed for all temperatures with extending austempering time, the conceivable reason is for isothermal duration past 30 minutes, the bainitic transformation proceeds on austenite grain interface, bringing about nucleation and growth of individual bainitic ferrite plates.
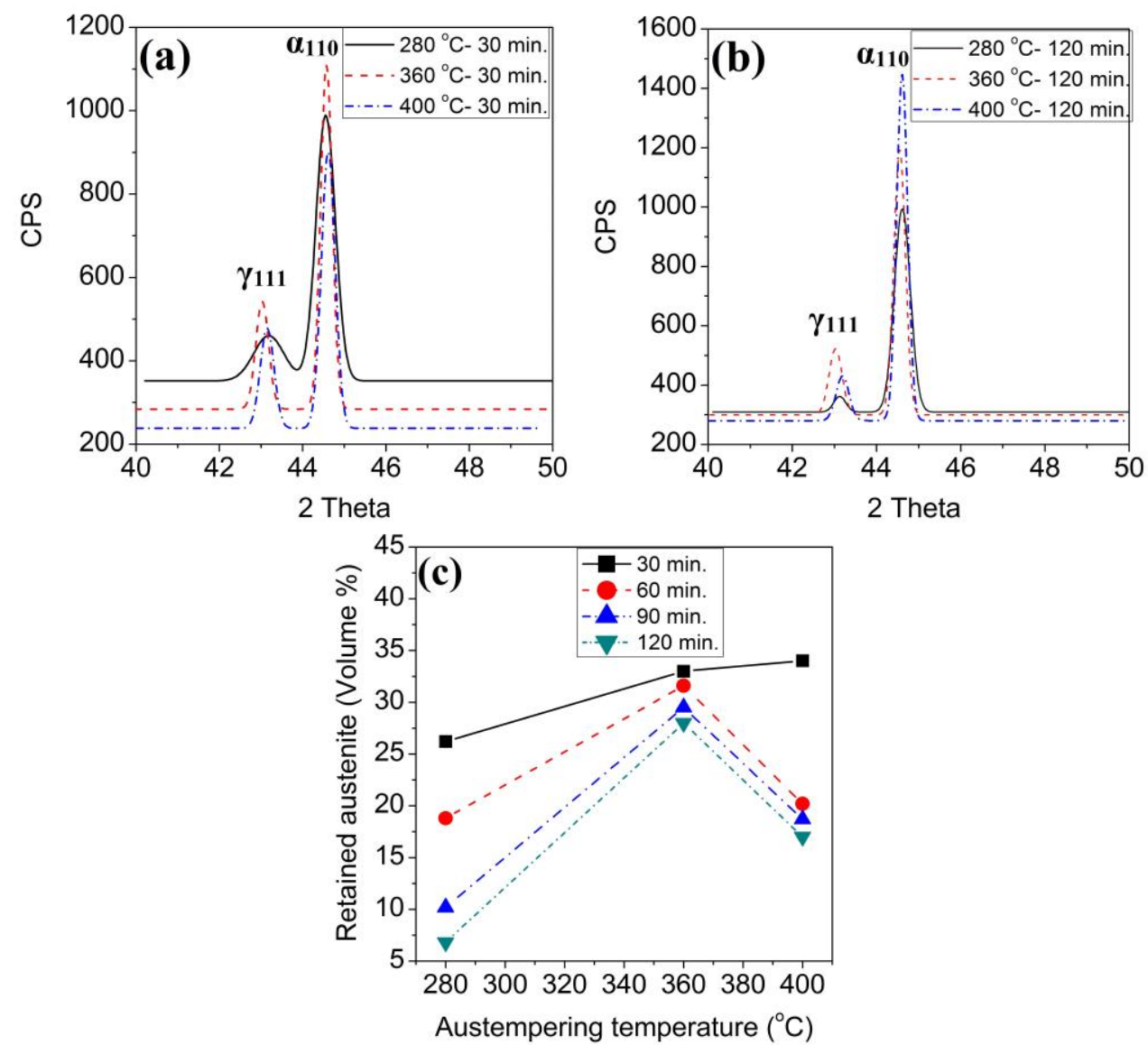

Fig. 2. (a) XRD patterns for samples austempered at 280,360 and $400^{\circ} \mathrm{C}$ for 30 minutes.

(b) XRD patterns for samples austempered at 280,360 and $400^{\circ} \mathrm{C}$ for 120 minutes.

(c) Retained austenite (volume \%) as a function of austempering temperature and time.

The blend of ferrite laths inciting the course of action of a greater bainitic ferrite lath enables a more prominent measure of austenite to be as blocks rather than film morphology. Consequently bainitic ferrite content increments and hence the retained austenite content decreases for extended isothermal duration [8].

\subsection{Vickers hardness}

Fig. 3 shows variation of hardness as a function of varying austempering parameters.

The hardness of the material decreases with increase in austempering temperature for all austempering time (particular case for 120 minutes $595 \mathrm{HV}$ to $378 \mathrm{HV}$ ). At lower 
austempering temperature of $280^{\circ} \mathrm{C}$, the microstructure comprising of acicular bainitic ferrite, retained austenite and martensite contributes for high hardness.

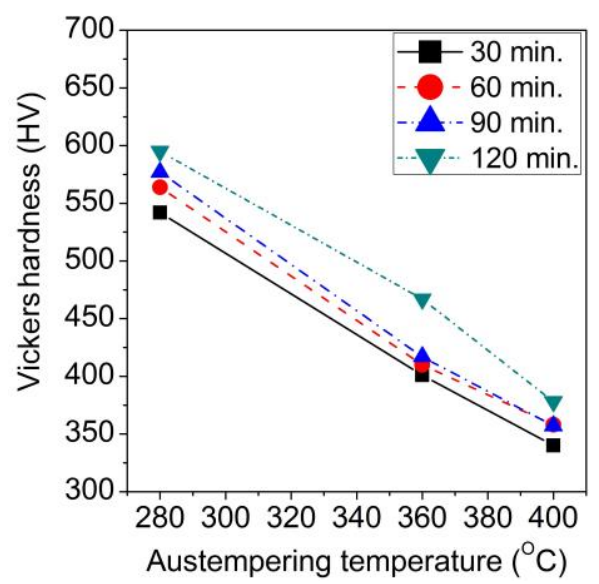

Fig. 3. Vickers hardness as a function of austempering temperatures and duration.

At elevated austempering temperatures at $360^{\circ} \mathrm{C}$ and $400^{\circ} \mathrm{C}$, the increased coarseness of bainitic ferrite and retained austenite results in lower hardness to the matrix.

\subsection{Wear property}

Specific wear rate (SWR) reveals very small increase with extending austempering temperature and time (Fig. 4(a)). This was ascribed to the way that while extending the austempering time, retained austenite content decreases, accordingly SWR shows marginal increase (Fig. 4(b)), which implies higher retained austenite content favors to enhance wear resistance.
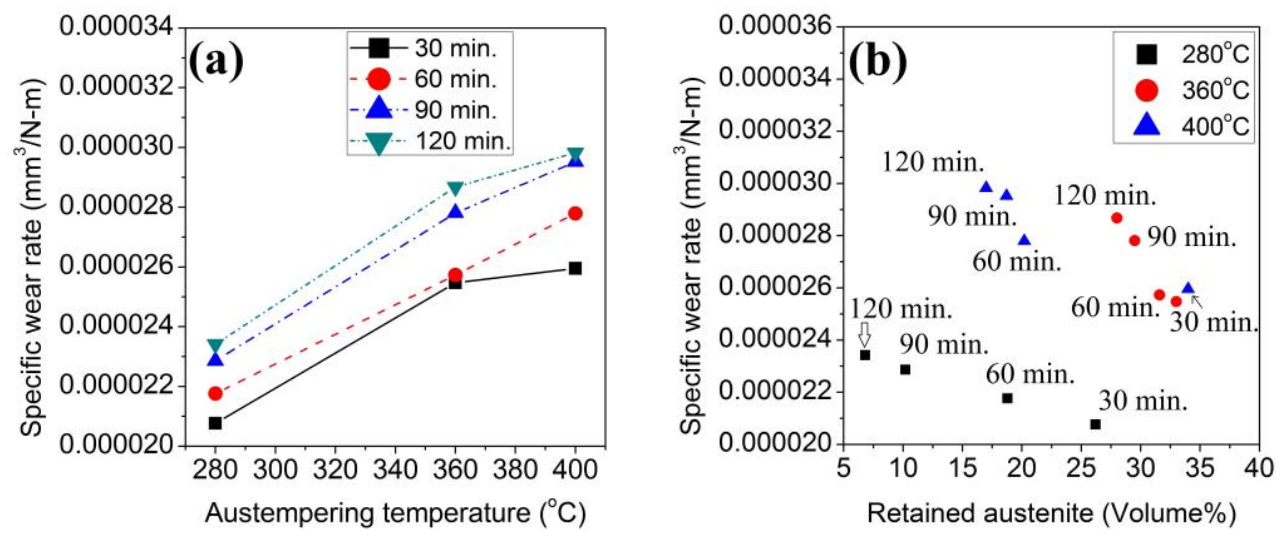

Fig. 4. (a) Specific wear rate as a function of austempering temperatures and duration. (b) Specific wear rate as a function of retained austenite content.

The sample austempered at $280^{\circ} \mathrm{C}$ for 30 minutes, here the growth of fine acicular ferrite along with stabilized austenite and martensite adds to the lower SWR, despite the fact that the hardness value of $280^{\circ} \mathrm{C}$ for 30 minutes sample is lesser contrasted with those of examples austempered at higher duration (Fig. 3), the fundamental explanation for this is 
hardening amid wear, were the specimens with low hardness tends to harden amid deformation i.e., a greater amount of the retained austenite content experiences transformation to martensite [9] during wear bringing about high surface hardness, which was confirmed by microhardness measurements (load $=200$ grams and dwell time $=30$ seconds) on the light and dark regions of the worn surface (Fig. 5(a)), light regions showed a maximum hardness value of $860 \mathrm{HV}$ which implies transformation from retained austenite to martensite and dark areas are oxidized debris that exhibits high hardness in the range 950 to $1160 \mathrm{HV}$. Hence the material removal decreases due to adhesive and abrasive forces, in this manner enhances the wear resistance. Wear resistance is obtained by a blend of hardness and toughness of materials, by temperance of sliding contact, hardness assumes an imperative part in wear resistance, inferable from the little impact in the midst of sliding friction. Additionally, increase in austempering temperature, hardness of austempered samples reduces, bringing about higher SWR.

\subsubsection{Wear mechanism}

After completion of wear test, the worn surfaces of the austempered specimens were characterized using SEM in order to understand the wear mechanisms (Fig. 5). Initial stages sliding wear was the predominant mechanism of material removal. The wear debris is pushed into the contact and is smeared by the acting forces. The main damage mechanisms observed in different austempered high silicon steels, due to sliding contact were adhesion, indentation and surface fatigue.
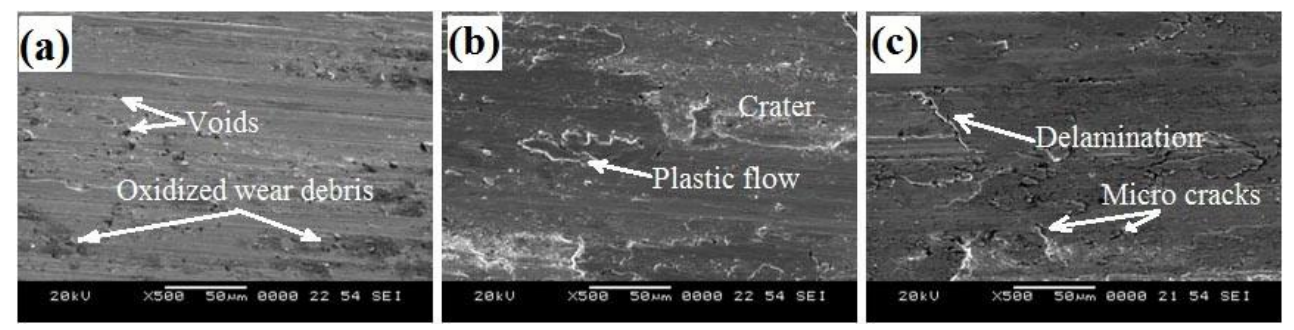

Fig. 5. Scanning electron micrographs of worn out samples austempered at (a) $280^{\circ} \mathrm{C}-30$ minutes (b) $360^{\circ} \mathrm{C}$ - 120 minutes (c) $400^{\circ} \mathrm{C}$ - 120 minutes

During the wear process formation of micro cracks, voids, crater, oxides, plastic flow of material and delamination takes place. The voids are the initiator of the crack formation; therefore crack will form near to voids. The linkage of voids enhance delamination of worn surface or in other words the sub surfaces present below the worn out surface propagates and comes out at the surface and shows delamination. Further running-in time the test specimen undergoes plastic shearing and indentation damage takes place due to hard wear debris [10].

\section{Conclusions}

The following conclusions were drawn from the present study on microstructural aspects and wear behaviour of austempered AISI 9260 high silicon steel.

- Austempering heat treatment of this steel over a temperature range 280 to $400^{\circ} \mathrm{C}$ generates ausferritic microstructure consisting of bainitic ferrite and retained austenite. 
- Retained austenite content was found to be maximum at $360^{\circ} \mathrm{C}$. Decrease in retained austenite content was observed with increasing austempering time for all temperatures.

- Hardness decreases as the austempering temperature increases, mainly due to the increase in coarseness of bainitic ferrite and austenite. Increase in austempering time showed moderate increase in hardness for all austempering temperatures.

- Specific wear rate shows marginal increase with the increase in austempering temperature and time. However specimen austempered at $280^{\circ} \mathrm{C}$ for 30 minutes offered superior wear resistance i.e. least specific wear rate.

- Formation of voids, micro cracks, oxide debris and surface delamination was observed in almost all worn out samples.

\section{Acknowledgement}

The authors gratefully acknowledge Steelmart, Mumbai, India for providing us this specific grade of steel as per our requirement. We are also thankful to National Institute of Technology Karnataka, Surathkal, India for providing us the financial support and facilities to carry out this investigation.

\section{References}

1. S. K. Putatunda, V. S. Arjun, T. Ronald and L. Gavin, Material Science and Engineering A 513-514, 329 (2009)

2. S.K. Putatunda, Materials and Design 24, 435 (2003)

3. D. Mandal, M. Ghosh, J. Pal, P.K. De, G. S. Chowdhury, S. K. Das, G. Das and S. Ghosh, Journal of Material Science 44, 1069 (2009)

4. S. Sharma, S. Sangal and K. Mondal, Metallurgical and Materials transactions A 42A, 3921 (2011)

5. L. C. Chang, Wear 258, 730 (2005)

6. A. S. T. M. G99 Standard, ASTM International, (West Conshohocken, PA 2008)

7. B. D. Cullity, Elements of X-Ray Diffraction (Addison-Wisley, Reading, MA, 1974)

8. C. Liu, Z. Zhao and S. D. Bhole, Materials Science and Engineering A 434, 289 (2006)

9. J. Yang, T. S. Wang, B. Zhang and F.C. Zhang, Scripta Materialia 66, 363 (2012)

10. A. Leiro, A. Kankanala, E. Vuorinen and B. Prakash, Wear 273, 2 (2011) 